\title{
GENDER ROLES INCLIMATE CHANGE ADAPTATION STRATEGIES BY CASSAVA- FARMERS IN GOKANA LOCAL GOVERNMENT AREA, RIVERS STATE
}

\author{
Henri-Ukoha, A. ${ }^{1}$, Ugwuja, V.C. ${ }^{1}$, Oladejo, E.E. ${ }^{2}$, Zigakolbari, N. ${ }^{1}$ and Onyemma, G. ${ }^{1}$ \\ ${ }^{1}$ University of Port Harcourt, Port Harcourt, Nigeria \\ ${ }^{2}$ Department of Agricultural Extension, University of Ibadan, Nigeria \\ Corresponding author: adanna.henri-ukoha@uniport.edu.ng
}

\begin{abstract}
The study examined gender roles in climate change adaptation strategies used by cassavabased farmers in Gokana Local Government Area of Rivers State, Nigeria. It specifically described the socio-economic characteristics of cassava farmers across all gender levels, identified adaptation strategies practiced by these farmers across gender levels and the problems encountered by cassava farmers in the use of adaptation strategies in the study area. Multi-stage sampling technique was used to select 60 respondents in the study area. Data were analyzed using descriptive statistics. The results of socio-economic characteristics of the farmers showed that $56.6 \%$ of the male farmers were married which is greater than $46.60 \%$ of the married females. The males had more average income of $\$ 1,620,000.13$ compared to 133,000.66 for the females. The females had more farm experience than the males, while the male cultivated larger farms. The main adaptation strategies used by cassava farmers in the study area were change of planting date, moving to a different site, mixed cropping and changing the timing of land preparation. Irregular extension services were the major constraint faced by the cassava farmers with a mean value of 3.722 for male farmers and mean of 4.411 for female farmers. It is concluded that gender plays several roles in climate change adaptation strategies in cassava-based farming in the study area. Based on the findings, efforts should be made by government and relevant stakeholders to educate cassava farmers on climate change adaptation strategies along gender lines.
\end{abstract}

Keywords: Gender, adaptation strategies, roles, climate change, cassava-based farmers https://dx.doi.org/10.4314/jafs.v16i1.7

\section{INTRODUCTION}

Africa is the largest producer of cassava compared to other continents, with $62 \%$ share of the total world production of cassava (Sanni et al., 2009). Nearly two-thirds of total cassava production in Africa (38.3 million tones) is grown in Nigeria, making it the largest in the world with about $19 \%$ of global market (Adebayo et al., 2009). Cassava is the most important staple 
crop in Nigeria. Cassava contributes to the well-being of Nigerians both as a subsistence crop for household and as a commodity for commercial purposes (Kalu, 2006). Cassava is a food security crop and perceived as a "Famine fighter" (Henri-Ukoha et al., 2011), with high poverty reduction potential due to low cost of production (Asante-Pok, 2013). Although Nigeria grows cassava in large quantities, its cultivation is on a small-scale level, often in fields to be set aside as fallow or even cropped on marginal soils, replacing crops that require greater soil fertility (Adebayo et al., 2009). Climate change which is characterized by natural climate cycle and human activities, has adversely affected agricultural productivity in Nigeria (Ziervogel et al., 2006). As the planet warms, rainfall patterns shift and extreme events such as drought, flood and forest fires become more frequent, this results in poor and unpredictable yields which subject farmers to vulnerable circumstances (United Nation Framework and Convention on Climate Change, 2007).

Gender roles are patterned by different social and cultural contexts they exist in. Certain factors like country/region, ethnic group, age, economic class and religion all have an effect on which roles and responsibilities that men and women, boys and girls are expected to have (FAO, 2012). This considers the concerns and experiences of both women and men as an integral dimension of all agriculture and rural development efforts.

Adaptation to climate change refers to a general plan for addressing the impacts of climate change, including climate variability and extremes. It includes a mix of policies and measures selected to meet the overreaching objective of minimizing the country's vulnerability (United Nations Development Programme, 2006).

Despite the overriding position of cassava in Nigerian agriculture, the perception of farmers and their attitude towards cassava production are often poor and left in the hands of peasants farmers who mostly produce at subsistence level. The socio-economic characteristics of individual households have been identified as basic factors that influence the food security status of households (Sanusi \& Salimonu, 2006). On the other hand, the natural resource base on which these farmers depend will be altered, traditional socio-economic safety nets will be stressed and the potential for future agricultural development will be affected with the lingering climate change saddle (Food Agricultural Organization, 2012).

In the same way, since agricultural production in Nigeria relies mainly on rainfall for water, climate change may result in loss of agricultural land with shorter growing season and lower yields and could expose more people to risk of hunger (Fischer, 2002).In addition, farmers who constitute the bulk of the poor in Nigeria face challenges of tragic crop failures, reduction in agricultural productivity, increase in hunger, malnutrition and disease (Apata, Samuel \& Adeola, 2009). This climate change variability is worsened as some developed cassava varieties are not acclimatized to the rural environment; not built on the indigenous knowledge of the farmer to provide for sustainability of the new practices (Ajayi, 2016). More so, social inequalities put 
many poor people on the frontline of dangerous climate change impacts while constraining their options for taking action to reduce it through adaptation (Casteneda \& Acquah, 2012). These are evident in the impeding land tenure system and shortage of labour which thus inhibit the collective participation of all gender towards ameliorating the harmful excesses of climate change. Furthermore, problem of climate change adaptation will result to decline in production as expenses on cassava production is not commensurate to the investment thereby scaring the vulnerable poor cassava farmers from active involvement in cassava production. Other problems are poor irrigation system, inadequate information, inadequate capital and low technical knowhow across gender participants in cassava production.

This implies that critical awareness of effective measures to deal with gender inequalities are important for the development and formulation of policies and programmes that can tackle the issue of climate change (Casteneda \& Acquah, 2012). It is on these foregrounds that this study examined gender roles in climate change adaptation strategies used by cassava-based farmers in Gokana Local Government Area of Rivers State, Nigeria. Specifically, the paper described the socio-economic characteristics of cassava-based farmers across all gender levels in the study area; identified the adaptation strategies practiced by cassava- based farmers across all gender in study area; and identified the problems encountered by cassava-based farmers across all gender levels in the use of adaptation strategies in the study area.

\section{MATERIALS AND METHODS}

The study was conducted in Gokana Local Government Area of Rivers State. Gokana is one of the twenty three Local Government Areas in Rivers State. Gokana Local Government Area is located within latitudes $4^{0} 23^{1}$ and $4^{0} 50^{1} \mathrm{~N}$ and longitudes $7^{0} 21^{1}$ and $7^{0} 35^{1} \mathrm{E}$. it has an annual total rainfall of between $160 \mathrm{~mm}$ to $298 \mathrm{~mm}$, with a relative humidity of over $90 \%$ and mean annual temperature of $27^{\circ} \mathrm{C}$. The Local Government also constitute a population of 328,500 people, occupying a land area of $126 \mathrm{~km}^{2}$, with a density of $2607 / \mathrm{km}^{2}$ (Udom, Ushie \& Esu, 2002). It is comprised of 8 fishing communities which include; Mogho, K.dere, Bomu, Lewe, Kpor, B.dere and Gbe and 9 inland communities which are: Bera, Nweol, Giokoo, Biara, Deeyor, Nwee Biara, Yeghe, Barako and Denken whose occupations are predominantly arable crop farming. The crops grown in the area are cassava, maize, pumpkin, pepper and yam. The major climatic variable affecting the farmers in Gokana are flood and increase in atmospheric temperature.

Multi-stage sampling technique was used in the study. In the first stage, ten (10) communities were selected purposively from the 17 communities in the study area. This was to get the cassava based farmers in the study area. In the second stage, a compiled list of registered cassava based farmers in the ten communities was obtained from the Agricultural Development Programme Extension Agents resident in the selected communities. From the list, three (3) each of cassavabased male and female farmers respectively were selected randomly from each community. This 
Journal of Agriculture and Food Sciences

Volume 16 Number 1, April 2018 pp. $79-90$.

gave a total of thirty male cassava-based farmers and thirty female cassava-based farmers in the study area, thus making a total sample size of 60 respondents. Data were collected through the use of questionnaire and interview schedule.

Data were analyzed using descriptive statistical tools such as frequency counts, percentages and mean.

\section{RESULTS AND DISCUSSION}

\section{Socio-economic Characteristics of the Respondents}

Table 1 above shows that $40 \%$ of the males were within (51-60) years of age while $13.30 \%$ fell within the age of $(30-40)$ years of age with an average age of 49 years. Similarly, $50 \%$ of the females were within $(51-60)$ years while $6.60 \%$ fell within $(30-40)$ years of age with a mean of 52 years. This is consistent with the findings of Ayoada (2012) who observed that the cassavabased farmers are young and energetic and they have the strength to practice the adaptation strategies.

The results indicate that $40 \%$ of the males acquired primary education and about $13 \%$ acquired tertiary education, while about $33.4 \%$ of the females had attained primary education and $10 \%$ had attained tertiary education, thus signifying that majority of the cassava-based farmers attended primary school. This result is in conformity with the findings of Akinwalere et al., (2016) which revealed that greater percentage of cassava farmers attended secondary school. This signifies that the farmers were educated; although the male farmers were more educated than the female ones. Their high interest in schooling could be because education exposes farmers to innovations and also helps them to adopt them faster.

The findings from Table 1 further reveals that $46.68 \%$ of the males' household sizes were within 6-10 persons, while $16.66 \%$ were within the household size of 11-15 persons and the mean household size for males was 10 persons. On the other hand, 50\% of the females' household sizes were within the range of 6-10 persons while $20 \%$ fell within 11-15 persons with the mean household size of 8 persons for female farmers which corresponds with the result of Ayoade (2012). This indicates that male respondents have larger household size than the female respondents in the study area. This could be due to the fact that males are mostly polygamous. The average household size in both group of farmers imply the availability of farm hands which enhance productivity and the practice of more adaptation strategies.

This table shows a mean farm size of 4.45 hectares and 2.83 hectares for male and female farmers respectively. This might be as a result of land tenure system practice in the study area in which lands are mostly allocated to males more than females (Emenyeonu, Henri-Ukoha, Onyemauwa \& Okafor, 2018). This also shows that both female and male cassava-based farmers Journal of the Faculty of Agriculture and Veterinary Medicine, Imo State University Owerri website: www ajol.info 
in the study area are mostly on smallholder farmers, hence, may influence the adoption technology, scale of production, output level as well as the tendency to adopt substantial information to improve on climate change.

It is observed from the table that $56.60 \%$ of the male farmers and $46.60 \%$ of the female farmers were married. The results also reveal that $13.40 \%$ of the males and $6.60 \%$ for female respondents were divorcees while $20 \%$ of the males and $13.40 \%$ of the females were single. However, $10 \%$ of the males and $33.40 \%$ of the females were widows and widowers. The result is in line with the observations of Ezikiel et al. (2012) where they stated that majority of the cassava farmers were married. This indicates that there were more married male cassava-based farmers than their female counterparts in the study area. The male farmers who were married are more likely to engage in economic activities that demand they live sedentary or more settled live style which will enable them concentrate on ways to adapt to varying effect of climate change more than the female cassava-based farmers who had lower percentage of married people.

A percentage of 33.40 of male farmers and 26.60 of female farmers were members of cooperative whereas $66.3 \%$ of males and $73.4 \%$ of females were not. Even as majorities were not members of cooperative societies, male farmers had 33.40 percentages of people who were members of cooperative which is higher than that of the female farmers with a percentage of $26.60 \%$. This might be as a result of male farmers been more educated than the female farmers as shown in their level of education.

The mean farming experience was 20 years for male farmers and 22 years for female farmers which show that female farmers are more experienced than the male farmers. This can be attributed to the fact that more males go to school while females who do not go to school engage in farm work earlier in life implicating for girl child education (Chikezie, et al., 2016).

The male farmers (30\%) comparatively had more contact with extension agents than the female farmers $(20 \%)$. Although, male farmers had more access to extension agents than the female farmers, but both have limited access to extension agents with $80 \%$ of female farmers and $70 \%$ of male farmers not having access to extension agents. This is not encouraging because contact with or visit made by extension agents provide opportunity for transfer of skills, knowledge and information which facilitate climate adaptation strategies.

The results further reveals the mean income of the male farmers as $\$ 162,000.13$ and that of the female farmers as $\$ 133,000.66$. This indicates that, the male cassava-based farmers have more average income than the female cassava-based farmers in the study area. This might be that larger household size and more access to farmlands to male farmers than to female farmers served as an edge to the male farmers to gain more average income over the female farmers and

Journal of the Faculty of Agriculture and Veterinary Medicine, Imo State University Owerri website: www ajol.info 
Journal of Agriculture and Food Sciences

Volume 16 Number 1, April 2018 pp. $79-90$.

therefore, suggest the possibility of women being more vulnerable than men in adapting to climate change (Enete, 2009).

\section{Adaptation Strategies}

Table 2 showed that moving to a different site for the males and change of planting date for females were the most significant adaptation option used in the study area to reduce the adverse effect of climate change. The male farmers also adopted mixed cropping (80\%) and change in the time of land preparation $(70 \%)$ while the female farmers prefer changing the timing of land preparation (80\%) and changing the harvest date $(73.33 \%)$. Others include: use of early maturing crop varieties for females (20\%) and use of irrigation/ground watering for males (16.66\%), but their low percentages suggest that they are not considered as major adaptation strategies in the study area.

\section{Problems encountered by the farmers}

From Table 3, it can be seen that the major constraint faced by the cassava-based farmers in the study area was irregular contact with extension agents which has a mean value of 3.722 for male respondents and 4.411 for female respondents. This implies that they hardly have extension agents visiting them and this therefore pose a problem to them because, they will not be exposed to various information on how to adapt to climate change, hence boost their capacity to increase output. The findings also show that the farmers were faced with lack of access to improved crop varieties; with a mean of 3.533 for male respondents and 4.323 for female respondents. This implies that, the cassava stems the respondents were planting have no resistance to unfavourable effects from climate changes, therefore may result to reduced yield, income, and standard of living. Non-availability of credit facilities which a mean of 3.176 for male respondents and 4.220 for female respondents also cause a great challenge to the farmers as they are not able to purchase the right materials needed for their production. The farmers in the study area also faced the following constraints as: absence of government policy on climate change with mean of 3.321 for male and 4,141 for female, low access to land with mean of 2.523 for male and 4.476 for female, limited knowledge on adaptation measures; with mean of 3.224 for male respondents and 3.102 for female respondents, limited access to water supply with mean of 3.112 for male respondents and 3.091 for female respondents as the major constraints in the study area.

\section{CONCLUSION}

Based on the results of the study, male cassava-based farmers had more average income, formal education and larger household size than their female counterparts, whereas the female cassavabased farmers had more years of farming experience than the male farmers. From the findings, gender affected the roles played by cassava-based farmers in adapting to climate change. The Journal of the Faculty of Agriculture and Veterinary Medicine, Imo State University Owerri website: www ajol.info 
main adaptation measure used by both male and female cassava-based farmers in the area is the change in planting date. However, male cassava-based farmers used more of the climate change adaptation strategies than the females as evident in use of credit facilities to increase production, planting different crop varieties and movement to a different site while change of planting date and change of harvest date were used more by the female farmers in the study area. However, the most serious constraint faced by cassava-based farmers in adaptation to climate change is irregular contact with extension agents.

\section{RECOMMENDATIONS}

Efforts should be made by government and relevant stakeholders to educate cassava-based farmers on climate change adaptation strategies along gender lines. Also, land use policy should be revisited to enable farmers have more access to farmland.

Journal of the Faculty of Agriculture and Veterinary Medicine, Imo State University Owerri website: www ajol.info 
Journal of Agriculture and Food Sciences

Volume 16 Number 1, April 2018 pp. $79-90$.

\section{REFERENCES}

Adebayo, A. S., Haggblade, I., Sanni \& Westby (2009). Innovations for Agricultural value chains in African: Applying science and technology to enhance cassava. Meridian Institute.

Apata, T., Samuel, K. D. \& Adeola, A. O. (2009). Analysis of climate change perception and adaptation among arable food crop farmers in South Western Nigeria. A paper presented to the International Association of Agricultural Economists in China. 209, 16 - 22.

Ajayi, J. O. (2016). Adaptation strategies to climate change by farmers in Ekiti State, Nigeria: Msc Thesis. Federal University of Technology Owerri.

Akinwalere, B. O., Adeleke, M. C. \& Ojo, A. O. (2016). Appraisal of the level of awareness and adaptation to climate change on cassava production in Ondo State Nigeria. Journal of Scientific Research \& Reports, 10(4), 1 - 7.

Asante-Pok A., 2013. Analysis of incentives and disincentives for cassava in Nigeria. Technical notes series, MAFAP, FAO, Rome.

Ayoade, A. R. (2012). Determinants of climate change on cassava production in Oyo State, Nigeria. GlobalJournal of Scientific Frontier Research, Agriculture \& Biology, 12(3), $2249-4626$.

Casteneda, A. C. \& Acquah, N. K. (2012). Why CARE International is making gender equality and women's empowerment a priority for community-based adaptation: CARE Insights $\begin{array}{lllll}\text { pp. } & 96 & - & 97 . & \text { Retrieved }\end{array}$ http://insights.careinternational.org.uk/media/k2/attachments/care-issue-brief-gender.pdf

Chikezie, C., Ibekwe, U. C., Ohajianya, D. O., Orebiyi, J. S., Henri-Ukoha, A., Ukoha, I. I., Osuji, M. N. \& Anthony, G. (2016). Climate change and perceived climate hazards: A trend analysis in South-East, Nigeria. International Journal of Weather, Climate Change and Conservative Research, 2(1), $1-10$.

Emenyeonu, C. A., Henri-Ukoha, A., Onyemauwa, C. S. \& Okafor, R. M. (2018). Alleviating climate change and threat to Nigeria's food security via organic agriculture: In J. C. Obiefune, A. B. I. Udedibie, G. E. Osuji, M. C. Ofoh, D. I. Osuigwe, E. U. Onweremadu \& E. B. Etuk (Eds.): Proceedings of the $5^{\text {th }}$ national conference of Organic Agriculture Project in Tertiary Institutions in Nigeria held at Federal University of Technology Owerri on $15^{\text {th }}-19^{\text {th }}$ November, 2009.

Enete, A. A. (2009). Challenges of agricultural adaptation to climate change: The case of cassava post-harvest in South- East, Nigeria. Department of Agricultural Economics University of Nigeria, Nsukka.

Ezikiel, A. A., Olawuyi, S. O., Ganiyu, M. O., Ojodokun, I. K. \& Adeyemo, S. A. (2012). Effect of climate change on cassava productivity in Ilesa- Easr Local Government Area of Osun State, Nigeria. British Journal of Art and Social Sciences, 10 (2), 2046 - 9578. Retrieved from: http://www.bjournal.co.uk/RJASS.aspx

Journal of the Faculty of Agriculture and Veterinary Medicine, Imo State University Owerri website: www ajol.info 
Food and Agriculture Organization (2012). Gender and climate change research in agriculture and food security for rural development: Training Guide. Rome: Retrieved from: http://www.fao.org/docrep/013/12050e/i2050e00.htm.

Food and Agriculture Organization (2011). The state of food and agriculture: Closing the gender gap for development. Rome. Retrieved from: http://www.pubmedcentral.nih,gov/articlerender.fcgi?artid=3291936\&tool=pmcentrez\&r endertype $=$ abstract

Fischer, G., Mahendra, S. \& Harrij, V. V. (2002). Climate change and agricultural variability: A special report on climate change and agricultural vulnerability. Johannesburg. Global agriculture.

Henri-Ukoha, A., Orebiyi, J.S, Ohajianya, D.O\&Ibekwe, U.C. (2011a). The Level of Food Security/Insecurity by Gender in selected land tenure systems among cassava-based farmers in Abia state, South East Nigeria: A comparative Analysis, International Journal of Agriculture and Food Science. UniversalResearch Publications (URP), India, 1(4), 6674

Kalu, N. N. (2006). Cassava revolution in Nigeria. Food Security Magazine, 12-14.

Sanni, L. O., Onadipe, O. O., Ilona, P., Mossagy, M. D., Abass, A. \& Dixon, A. G. O. (2009). Success and challenges of cassava enterprises in West Africa: A case study of Nigeria, Benin and Sierra Leone. International Institute of Tropical Agriculture, Ibadan, Nigeria. p. 19.

Sanusi, W. A. \& Salimonu, K .K. (2006). Food security among households: Evidence from yam production economics in Oyo State, Nigeria [Online]. Agricultural Journal, 1(4), 235259. [Accessed $11^{\text {th }}$ October, 2015].

Udom, C. J., Ushie, F. A. \& Esu, E. O. (2002). Agro-chemical survey of groundwater in Khana and Gokana Local Government Area of Rivers State, Nigeria: Journal of Applied Sciences and Environmental Management, 6 (1), 53 - 59.

United Nation Development Programme, (2006). Human Development Report: Power, poverty and the global water crisis. Retrieved from: http://hdr.undp.org/hdr2006/report/htm7.

United Nations Framework Convention on Climate Change (2007).

Ziervogel, G., Bharwani, S. \& Downing, T. E. (2006). Adapting to climate variability: Pumpkins, people and policy [online]. Natural Resource Forum, 30. 294 - 305. 
Journal of Agriculture and Food Sciences

Henri-Ukoha, A., Ugwuja, V.C., Oladejo, E.E., Zigakolbari, N. and

Volume 16 Number 1, April 2018 pp. 79 -90.

Table 1: Distribution of cassava-based farmers according to their socio-economic characteristics in the study area

\begin{tabular}{|c|c|c|c|c|}
\hline Variables & $\begin{array}{l}\text { Frequency of } \\
\text { Males }\end{array}$ & Percentage & $\begin{array}{l}\text { Frequency of } \\
\text { Females }\end{array}$ & Percentage \\
\hline \multicolumn{5}{|l|}{ Age (years) } \\
\hline $30-40$ & 4 & 13.30 & 2 & 6.60 \\
\hline $41-50$ & 9 & 30.00 & 10 & 33.40 \\
\hline $51-60$ & 12 & 40.00 & 15 & 50.00 \\
\hline $61-70$ & 5 & 16.70 & 3 & 10.00 \\
\hline Mean & 49 & & 52 & \\
\hline \multicolumn{5}{|c|}{ Education Level } \\
\hline $\begin{array}{l}\text { Non-formal } \\
\text { Education }\end{array}$ & 5 & 16.60 & 9 & 30.00 \\
\hline Primary & 12 & 40.00 & 10 & 33.40 \\
\hline Secondary & 9 & 30.00 & 8 & 26.60 \\
\hline Tertiary & 4 & 13.40 & 3 & 10.00 \\
\hline \multicolumn{5}{|c|}{ Household Size } \\
\hline $1-5$ & 11 & 36.66 & 9 & 30.00 \\
\hline $6-10$ & 14 & 46.68 & 15 & 50.00 \\
\hline $11-15$ & 5 & 16.66 & 6 & 20.00 \\
\hline Mean & 10 & & 8 & \\
\hline \multicolumn{5}{|c|}{ Farm Size (hectares) } \\
\hline$<2$ & 5 & 16.60 & 14 & 46.66 \\
\hline $2-4$ & 9 & 30.00 & 8 & 26.68 \\
\hline $5-7$ & 13 & 43.40 & 6 & 20.00 \\
\hline $8-10$ & 3 & 10.00 & 2 & 6.66 \\
\hline Mean & 4.45 & & 2.83 & \\
\hline \multicolumn{5}{|c|}{ Marital Status } \\
\hline Single & 6 & 20.00 & 4 & 13.40 \\
\hline Married & 17 & 56.60 & 14 & 46.60 \\
\hline Divorced & 4 & 13.40 & 2 & 6.60 \\
\hline Widowed & 3 & 10.00 & 10 & 33.40 \\
\hline \multicolumn{5}{|c|}{ Members of Cooperatives } \\
\hline No & 20 & 66.30 & 22 & 73.40 \\
\hline Yes & 10 & 33.40 & 8 & 26.60 \\
\hline \multicolumn{5}{|c|}{ Farming Experience } \\
\hline $1-10$ & 5 & 16.60 & 2 & 6.60 \\
\hline $11-20$ & 9 & 3.00 & 10 & 33.40 \\
\hline $21-30$ & 12 & 40.00 & 14 & 46.60 \\
\hline $31-40$ & 4 & 13.40 & 4 & 13.40 \\
\hline Mean & 20 & & 22 & \\
\hline \multicolumn{5}{|c|}{ Access to Extension Services } \\
\hline NO & 21 & 70.00 & 24 & 80.00 \\
\hline
\end{tabular}

Journal of the Faculty of Agriculture and Veterinary Medicine, Imo State University Owerri website: www ajol.info 


\begin{tabular}{lllll} 
YES & 9 & 30.00 & 6 & 20.00 \\
$\begin{array}{l}\text { Average } \\
50-100\end{array}$ & Income Level & & & \\
$101-150$ & 10 & 6.60 & 10 & 33.40 \\
$151-200$ & 12 & 33.40 & 8 & 26.60 \\
$>201$ & 6 & 40.00 & 9 & 30.00 \\
Mean & $\mathbf{1 6 2}$ & 20.00 & 3 & 10.00 \\
\hline
\end{tabular}

Source: Field Survey, 2017

Table 2: The Distribution of the Cassava-based farmers according to Adaptation Strategies practiced by gender in the study area.

\begin{tabular}{|c|c|c|c|c|c|c|c|}
\hline \multirow[b]{2}{*}{ Adaptation strategies } & \multirow[b]{2}{*}{$\mathbf{N}$} & \multicolumn{3}{|c|}{ Male } & \multicolumn{3}{|c|}{ Female } \\
\hline & & Mean & Freq & $\%$ & Mean & Freq & $\%$ \\
\hline Change of planting date & 60 & 0.8333 & 25 & 83.33 & 0.8666 & 26 & 86.66 \\
\hline Moving to a different site & 60 & 0.9000 & 27 & 90.00 & 0.6333 & 19 & 63.33 \\
\hline Mixed cropping & 60 & 0.8000 & 24 & 80.00 & 0.7000 & 21 & 70.00 \\
\hline $\begin{array}{l}\text { Changing the timing of land } \\
\text { preparation }\end{array}$ & 60 & 0.7000 & 21 & 70.00 & 0.8000 & 24 & 80.00 \\
\hline Changing harvesting date & 60 & 0.6333 & 19 & 63.33 & 0.7333 & 22 & 73.33 \\
\hline Planting crops with early rainfall & 60 & 0.6333 & 19 & 63.33 & 0.6000 & 18 & 60.00 \\
\hline Different crop varieties & 60 & 0.6333 & 19 & 63.33 & 0.4333 & 13 & 43.33 \\
\hline Shading and sheltering/tree planting & 60 & 0.5666 & 17 & 56.66 & 0.5000 & 15 & 50.00 \\
\hline $\begin{array}{l}\text { Use of credits facilities to increase } \\
\text { production }\end{array}$ & 60 & 0.5000 & 15 & 50.00 & 0.2666 & 8 & 26.66 \\
\hline Use of early maturing crops varieties & 60 & 0.2666 & 6 & 26.66 & 0.2000 & 6 & 20.00 \\
\hline $\begin{array}{l}\text { Increase use of irrigation/ground } \\
\text { water /watering }\end{array}$ & 60 & 0.1666 & 5 & 16.66 & 0.2333 & 7 & 30.00 \\
\hline Valid N (listwise) & 60 & & & & & & \\
\hline
\end{tabular}

Source: Field survey, 2017

Note: Male respondents $=30$; female respondents $=30$ 
Table 3: Distribution of the Cassava-based farmers according to problems encountered by gender in the study area.

\begin{tabular}{|c|c|c|c|c|c|}
\hline Problems & $\mathbf{N}$ & Rank & $\begin{array}{l}\text { Mean } \\
\text { for } \\
\text { male }\end{array}$ & $\begin{array}{l}\text { Mean } \\
\text { for } \\
\text { female }\end{array}$ & Rank \\
\hline Irregular extension contact with extension agents & 60 & $1^{\text {st }}$ & 3.722 & 4.511 & $1^{\mathrm{st}}$ \\
\hline Lack of access to improve crop varieties & 60 & $2^{\text {nd }}$ & 3.533 & 4.323 & $2^{\text {nd }}$ \\
\hline Absence of government policy on climate change & 60 & $3^{\text {rd }}$ & 3.321 & 4.141 & $5^{\text {th }}$ \\
\hline Low access to land & 60 & $9^{\text {th }}$ & 2.523 & 4.476 & $3^{\text {rd }}$ \\
\hline Limited knowledge on adaptation measures & 60 & $4^{\text {th }}$ & 3.224 & 3.102 & $9^{\text {th }}$ \\
\hline Limited access to water supply & 60 & $6^{\text {th }}$ & 3.112 & 3.091 & $10^{\text {th }}$ \\
\hline Poor government attention to climate change & 60 & $8^{\text {th }}$ & 2.780 & 2.990 & $11^{\text {th }}$ \\
\hline Low awareness level & 60 & $7^{\text {th }}$ & 2.661 & 2.771 & $12^{\text {th }}$ \\
\hline No access to credit & 60 & $5^{\text {th }}$ & 3.176 & 4.220 & $4^{\text {th }}$ \\
\hline Shortage of labour & 60 & $10^{\text {th }}$ & 2.502 & 3.553 & $8^{\text {th }}$ \\
\hline Lack of access to land & 60 & $12^{\text {th }}$ & 2.021 & 3.904 & $6^{\text {th }}$ \\
\hline Insufficient & 60 & $11^{\text {th }}$ & 2.156 & 3.887 & $7^{\text {th }}$ \\
\hline Valid N (listwise) & 60 & & & & \\
\hline
\end{tabular}

Note: male respondents $=30$; female respondents $=30$

Source: Field survey, 2017 